\title{
SOME FACTORS AFFECTING REPRODUCTIVE PERFORMANCE IN NORFA CHICKENS
}

\author{
M. A. A. Kalamah ${ }^{1}$, M. M. El-Nadi ${ }^{1}$, L. M. Goher ${ }^{2}$ and M. M. Soliman ${ }^{2}$ \\ 1- Department of Poultry Production, Faculty of Agriculture, Minufiya University, 2- Department \\ of Poultry Breeding, Animal Production, Research Institute, Giza, Egypt
}

\section{SUMMARY}

This work was carried out at the Farm of Poultry Production, Faculty of Agriculture, Minufiya University, Shibin El- Kom. Four trials were conducted as follows :Trial (1) : To study the effect of both body weight and months of the year on physical characteristics of semen. Thirty cocks were divided into equal two groups depending on body weight ; (HW) and (LW). Semen was individually collected for 9 months , from November to July. Trial (2): Semen was collected over 3 months from 60 cocks in 3 equal groups ; once, twice and three times weekly to study the effect of frequency of semen collection on physical characteristics of semen. Trial (3): To study the relationship between body weight (heavy VS light) and some seminal plasma constituents. Semen collected in pooling of each group. Blood samples were collected individually from (HW) and (LW) cocks to study the relationship of some blood constituents with semen production. Trial (4): Eggs were collected from 480 hens to study the effect of frequency of semen collection, semen dose, types of diluters and dilution rate on fertility and hatchability .

The results revealed that, sperm motility (SM) and abnormal sperm (SA) were significantly higher $(\mathrm{P} \leq 0.05)$ in $(\mathrm{LW})$ than $(\mathrm{HW})$ cocks. The opposite was true for the live sperm (SV). The ejaculate volume (EV), sperm concentration (SC) and semen pH were similar in both ( HW) and (LW) cocks. All semen physical characteristics significantly $(\mathrm{P} \leq 0.01)$ differed among months. As the frequency of ejaculation increased the (EV) significantly $(P \leq 0.01)$ decreased, $(\mathrm{SC})$ increased and $(\mathrm{SM})$ fluctuated.

The seminal total protein, globulin, A/G ratio, cholesterol, inorganic phosphorus, alkaline and acid phosphatases, GPT and GOT did not significantly differ between (HW) and (LW) cocks, meanwhile, that albumin, calcium and $\mathrm{Ca} / \mathrm{IP}$ ratio were significant $(\mathrm{P} \leq 0.05)$.

The blood total protein, albumin and globulin of high semen production cocks were significantly $(\mathrm{P} \leq 0.01)$ higher than that of low semen production ones. However, the blood cholesterol, inorganic phosphorus, alkaline and acid phosphatase activities were not significant different between high and low semen production cocks.

There were no significant differences between insemination doses and frequency of semen collection used on fertility and hatchability. The effect of dilution ratio and type of diluents was not significantly on egg fertility and hatchability. Vaginal $\mathrm{pH}$ of high fertility hens was significantly $(\mathrm{P} \leq 0.05)$ lower than that of low fertility ones.

\section{Keywords: Semen characteristics, artificial insemination, fertility, hatchability}

\section{INTRODUCTION}

Economic consideration continues to stimulate interest in application of artificial insemination in poultry farms. However, artificial insemination in chickens has been mainly limited to genetic and physiological studies, maintaining control and the development of new lines. In contrast, this technique is already used by the majority of turkey breeders.

Artificial insemination is considered as a valuable technique in poultry industry and research. One of advantages of its application over natural mating is the efficient use of males. Poultry semen must be extended before its efficient use, which allows the increase in numbers of inseminations per ejaculate. This in turn, decreases the cost of AI directly by reducing the number of males needed (Benoff et al., 1981 and Bootwalla and Froman, 1988). On the other hand, the modern housing system for poultry industry in individual cages, makes such a procedure to be the unique applicable one to produce fertile eggs. It is also considered as an important tool to solve some of the practical problems of crossbreeding in ducks (Kalamah, 1990). However, the ideal semen extender and dilution rate are not yet available.

Limited information are available concerning the physical and chemical characteristics of Norfa cocks semen. There are several factors could affect these traits. Therefore, the present study was carried 
out in order to investigate the effect of body weight, frequency of semen collection and month of year changes on the characteristics of Norfa cocks semen. Also the effect of semen extender, dilution rate and insemination dose on fertility and hatchability in Norfa hens were studied. This work can give helpful informations about factors influencing semen production of Norfa cocks as a new breed and also may help in application of artificial insemination in poultry flocks raised in ARE.

\section{MATERIALS AND METHODS}

This work was carried out at the Farm of Poultry Production, Faculty of Agriculture, Minufiya University, Shibin El-Kom. The study was run in four trails:

Trial (1)

To study the effect of cock body weight and months of the year, on physical characteristics of semen. 30 Norfa cocks after sexual maturity were divided into two equal groups (i.e. heavy weighed $2037 \mathrm{~g}$ VS light weighed $1744 \mathrm{~g}$ ). In this trial semen was individually collected from 30 cocks twice weekly over 9 months (from November to July).

Trial (2)

To investigate the effect of frequency of semen collection on physical characteristics of semen. Semen was collected over 3 months from 60 cocks in 3 equal groups which were subjected to 3 system of semen collection frequency, (i.e. once, twice and three times weekly). The cocks were individually raised in wire cages under good ventilation and illumination. Semen was collected using the massage method and, the ejaculate volume to the nearest $0.01 \mathrm{ml}$. using $1.00 \mathrm{ml}$ tuberculine syringe., mass motility according to Nagae et al. (1987), initial semen $\mathrm{pH}$ by comparative $\mathrm{pH}$ paper, percentage of live and abnormal sperms after staining with iosine and nigrosine and sperm concentration using Thomas - Zeis haemocytometer were measured .

Trial (3)

Blood and semen samples were collected from 10 cocks of heavy weight (HW) $(1920 \mathrm{~g})$ and other 10 light cocks (LW) (1570g). Total plasma proteins, albumin, calcium, inorganic phosphorus, cholesterol, activity of plasma alkaline and acid phosphatases were determined in both the blood and semen, and activity of GOT and GPT in the semen only according to Gornall et al. (1949), Rodkey (1965), Krawczynski and Osinski (1962), Bratkowski (1975), Btaszczyszyn (1976), Kind and King (1954) and Reitman and Frankel (1957), respectively.

Trials (4)

To study:

1- Effect of semen dosage and frequency of semen collection on egg fertility and hatchability :-

Semen was collected in pooling from 90 adult Norfa cocks on the same day of insemination to inseminate hens. 310 Norfa hens were divided into three groups which were inseminated with semen collected with once, two and three / week. Every group contained semen dose $(0.05,0.10$ and 0.15 ml.) of three subgroups.

\section{2 - Effect of diluters and dilution rate on egg fertility and hatchability:-}

Semen was collected in pooling from 60 adult Norfa cocks on the same day of insemination to inseminate hens twice weekly. The effect of two selected diluents namely Na-glutamic-Na Citrate glucose (GCG) and Tris with two dilution ratios ( $1: 3$ and $1: 5$ semen:diluent ) were tested 170 hens were divided into 5 groups ; 1 and 2 groups inseminated by GCG diluter with dilution ratio 1:3 and 1:5. The tris diluter (1:3 and 1:5) were used to inseminated groups 3 and 4 . A control (group 5 ) of hens was also included, which was artificially inseminated with undiluted semen. All hens were managed alike in individually wire cages. Eggs produced by hens were used to estimate fertility and hatchability . Fertility was calculated as percentage of total eggs set in the incubation. Hatchability was calculated as percentage of hatched eggs to fertile eggs. $\mathrm{pH}$ of vaginal hens was measured using comparative $\mathrm{pH}$ paper over 3 months . 


\section{Statistical analysis}

Data obtained were statistically analyzed according to Snedecor and Cochran (1973) and Gill (1978). Dancan's multiple range test was used for the multiple comparisons of means. Values expressed in percentages (i.e. fertility and hatchability) were obtained by retransformation from Arcsin to original a scales prior statistical analysis.

\section{RESULTS AND DISCUSSION}

\section{Semen physical characteristics}

\section{1 - Effect of body weight}

The sperm motility (SM) and abnormality (SA) of semen samples produced by the light weighed cocks ( $\mathrm{LW}$ ) were significantly greater $(\mathrm{P} \leq 0.05)$ than those produced by heavy ones ( $\mathrm{HW}$ ), (Table 1 ). The reverse was true for percentage of live sperms (SV), meanwhile, the ejaculate volume (EV), sperm concentration (SC) and semen $\mathrm{pH}$ were not significantly affected by body weight of cocks. The total spermatogenic output, (SA) and (SV) per ejaculate were considerably greater in the semen samples produced by the ( LW ) cocks as compared to those produced by the ( HW ) ones .

El-Hammady et al. (1995) reported that (EV) and (SM) were quite similar in both ( $\mathrm{HW}$ ) and (LW) Dandarawi cocks. They added that ( SC) and (SV) were higher and semen pH was lower in (HW) than that in (LW) Dandarawi cocks. Semen volume and $\mathrm{pH}$ showed an opposite trend in Fayoumi cocks. Moreover, Holcman et al. (1993) found that the (EV), (SM), ( SC) and ( SV) were higher in heavy cocks than light ones. An opposite trend was true for (SA) and semen pH. In this respect, Ramamurthy et al. (1989) reported that (EV) of semen, $\mathrm{pH}$ and (SA) showed significant positive correlation with body weights at 25 and 35 weeks old in White Cornish, meanwhile, (SC), (SM) and (SV) showed significant negative correlation. However, Kunev and Manolov (1988) found that body weight was correlated positively with either (SC) or ( SM) and negatively with (SA) in New Hampshire cocks. The differences between these results may be due to the differences of breeds used.

Table 1. Effect of body weight on semen physical characteristics (mean \pm S.E.)

\begin{tabular}{llll}
\hline \multirow{2}{*}{ Traits } & \multicolumn{2}{c}{ Body weight (B.W.) } & \\
\cline { 2 - 3 } & Eight $(1744 \mathrm{~g})$ & Heavy $(2037 \mathrm{~g})$ & Significance \\
\hline Sperm concentration $\times 10^{9} / \mathrm{ml}$ & $0.23 \pm 0.004$ & $0.22 \pm 0.004$ & N.S \\
Total sperm/ejaculate $\times 10^{9}$ & $2.57 \pm 0.086$ & $2.61 \pm 0.091$ & N.S. \\
Sperm motility & 0.59 & 0.57 & \\
Semen $\mathrm{pH}$ & $3.00 \pm 0.051$ & $2.84 \pm 0.050$ & $\mathrm{P}<0.05$ \\
Abnormal sperm (\%) & $7.84 \pm 0.015$ & $7.84 \pm 0.015$ & N.S. \\
Total abnormal sperm/ejaculate $\times 10^{9}$ & $22.06 \pm 0.605$ & $20.56 \pm 0.508$ & $\mathrm{P}<0.05$ \\
Live sperm $(\%)$ & 0.13 & 0.11 & \\
Total live sperm /ejaculate $\times 10^{9}$ & $76.95 \pm 0.887$ & $78.87 \pm 0.772$ & P $<0.05$ \\
\hline
\end{tabular}

N.S.: Not significant

\section{2- Effect of month of the year on semen production}

All semen physical characteristics were affected significantly $(\mathrm{P} \leq 0.01)$ by month of the year from November to July (Table 2). The (EV) decreased from November to April. The (EV) in November and December was greater than that in other months. The reverse trend was true for semen collected during March and April. The ( SC ), total sperms per ejaculate and (SM) declined gradually nearly from December until July. In April and May, $\mathrm{pH}$ of semen was significantly higher than that in other of months, while, in November and December lower values of semen $\mathrm{pH}$ were detected. The (SA) was lower value from December to March, while it was higher value from May to July. The (SV) was greater from December to February, but it was lower from May to June. The total (SA) and total (SV) decreased gradually from December to July. The interaction between body weight and months was significant $(\mathrm{P} \leq 0.01)$ for ( $E V)$ and $(\mathrm{P} \leq 0.05)$ for either ( $\mathrm{SC}$ ) or ( $\mathrm{SM})$.

Kamar et al. (1979) found that ( EV) in Fayoumi cocks showed a decline from a highest value during February to the lowest value during September, meanwhile, the Rhode Island Red, the highest was obtained during July and the lowest value in February and March. They also reported that the (SC), total sperms per ejaculate, ( SA) and ( SV) in Fayoumi cocks attained it's maximum value in March followed by a gradually decline till September. Moreover, El-Sharkawy (1981) and Attia et al. (1984) reported that there were significant effects season on ( EV), (SC), (SM), semen pH and (SA), while, there were no significant differences in (SV) due to season for Fayoumi cocks. Saied and AlSoudi (1975) found that the highest (EV) produced from New Hampshire cocks was in autumn and 
spring, while the lowest value was noticed during winter. They also reported that the (SV) in spring was higher than that in summer. Hafez (1968) showed that the avian sperms were motile over a wide range of temperatures from a low of $2{ }^{\circ} \mathrm{C}$ to a high of $43^{\circ} \mathrm{C}$ showing that the movement increased with the temperature increasing. The present study suggest that increase semen $\mathrm{pH}$ in April and May may be due to decrease in both (EV) and (SC) that causes a corresponding decrease in lactic acid production in semen, that results the increase in semen $\mathrm{pH}$. The decrease of $(\mathrm{EV}),(\mathrm{SC}),(\mathrm{SM})$ and (SV) in summer months may be due to high temperature (Kalamah, 1990 ).

\section{3- Effect of frequency of semen collection}

Table 3 shows that, the ( EV) declined significantly $(\mathrm{P} \leq 0.01)$ when the frequency of ejaculation increased. An opposite trend was true for ( $\mathrm{SC}$ ). The ( $\mathrm{SM})$ was significantly $(\mathrm{P} \leq 0.01)$ greater for semen collection once weekly than that for both twice and three times weekly. This may be due to larger ( EV ) for semen collection once weekly than others. However, semen pH, ( SA ) and (SV) were not significantly affected by semen collection frequency. The total sperm, abnormal and live sperms per ejaculate decreased with increasing times of semen collection.

Results of (EV) and ( SC) of chicken were reported with McDaniel and Sexton (1977) agree with present study. McDaniel and Sexton (1977) found that (EV) of semen collected 3 times weekly was significantly greater than that of semen collected 5 times weekly in both. White Leghorn and broiler cocks. They also indicated the sperm cells per ejaculate was significantly greater of broiler breeder type males ejaculated three times weekly than those ejaculated once or twice daily. They added that Leghorn males that ejaculated three times weekly produced significantly greater sperm cells per ejaculate than that of five times weekly, while once weekly had (SC) equal to three times weekly and had significantly more than five times weekly.

In turkey, as the frequency of ejaculation increased, the (EV)), (SC) and (SV) decreased (Buckland et al.,1980 and Ansah et al.,1984).In ducks, Kalamah (1990) reported that the (SM), (SV), (SA) for semen collected once weekly were higher than that for twice weekly, while $\mathrm{pH}$ of semen did not affect the semen frequency.

\section{Effect of body weight on seminal plasma constituents}

The total proteins, globulins and $A / G$ ratio in seminal plasma was not significant between (HW) and (LW) cocks, (Table 4). However, the albumin was significantly $(\mathrm{P} \leq 0.05)$ higher in $(\mathrm{HW})$ than in (LW) cocks. The results of Blesbois and Caffin (1992) indicated that seminal plasma albumin may be one of the motility stimulating factors in seminal plasma.

The seminal plasma cholesterol of (LW) was insignificantly greater than that of (HW) cocks. However, Ressequie and Hughes (1984) reported that the molar ratio of cholesterol to phospholipid and the mole percent of cholesterol remained essentially constant for the various time intervals. Differences that were detected had no apparent pattern and were probably indicative of procedural or chance variation rather than membrane changes. The ratios for spermatozoa membrane cholesterol to spermatozoa membrane phospholipid obtained were 0.22 to 0.38 .

The average of seminal plasma calcium of $(\mathrm{HW})$ was significantly $(\mathrm{P} \leq 0.05)$ lower than that of (LW) cocks. They were $7.25 \pm 0.30$ and $8.92 \pm 0.09 \mathrm{mg} / 100 \mathrm{ml}$., respectively (Table 4).In this respect, Hammond et al. (1964) found that the seminal plasma calcium from White Plymouth Rock males was $7.03 \pm 0.40 \mathrm{mg} / 100 \mathrm{ml}$. The seminal plasma inorganic phosphorus was nearly the same in heavy and light cocks $(5.17 \pm 0.11$ and $5.25 \pm 0.16 \mathrm{mg} / 100 \mathrm{ml}$., respectively). El-Sharkawy (1981) and Attia et al. (1984)) reported that total mean of seminal plasma inorganic phosphorus ranged from 6.95 to $7.50 \mathrm{mg}$ $1100 \mathrm{ml}$ of Fayoumi cocks. The seminal plasma $\mathrm{Ca} / \mathrm{IP}$ ratio was significantly greater $(\mathrm{P} \leq 0.05)$ in $(\mathrm{LW})$ than (HW) cocks.

The seminal plasma alkaline and acid phosphatases, GPT and GOT activities in (HW) and (LW) cocks were nearly similar. From Table 4 it is clear that acid phosphatase was higher than alkaline phosphatase in both heavy and light cocks. These results agree with that reported by Hammond et al. (1964). Bilgili et al. (1985) stated that in seminal plasma of White Leghorn, enzyme of (GOT) activity showed a significant positive relationship with increasing concentration of dead spermatozoa.

Effect of some blood plasma constituents on semen production

The total plasma protein, albumin and globulin of high semen production cocks were significantly higher than that of low semen production ones. While, A/G ratio was similar (Table 5). El-Zarkouny (1994) showed that when semen was collected from New Zealand White rabbits male, the ejaculate volume was $0.64 \pm 0.03 \mathrm{ml} \mathrm{semen,} \mathrm{serum} \mathrm{total} \mathrm{protein} 7.51 \mathrm{~g} / 100 \mathrm{ml}$, serum albumin $3.52 \mathrm{~g} / 100 \mathrm{ml}$ and serum globulin $4.05 \mathrm{~g} / 100 \mathrm{ml}$. 

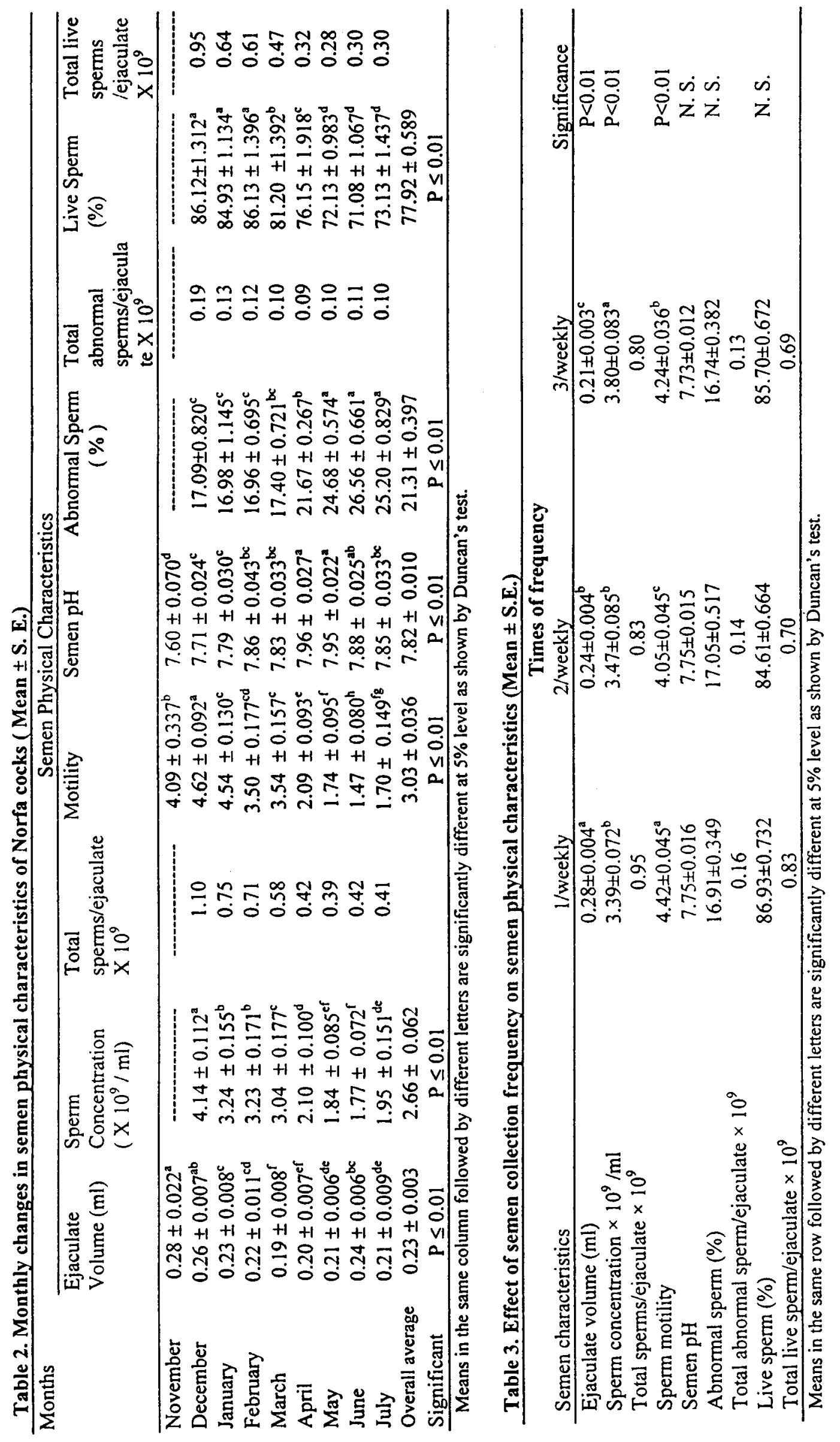
The plasma cholesterol of high and low semen production cocks was not significant $(129.57 \pm 3.16$ and $138.37 \pm 3.81 \mathrm{mg} / 100 \mathrm{ml}$, respectively, Table 5). However, El-Zarkouny (1994) reported that serum cholesterol concentration was $55.25 \mathrm{mg} / 100 \mathrm{ml}$ with ejaculate volume of semen $0.64 \pm 0.03 \mathrm{ml}$ of New Zealand White rabbit.

The average of plasma calcium, inorganic phosphorus, $\mathrm{Ca} / \mathrm{IP}$ ratio, alkaline and acid phosphatases of high and low semen production cocks were nearly similar. Abaza et al. (1995) reported that plasma calcium concentration was $3.63 \mathrm{mmol} / \mathrm{L}$ with ejaculate volume of semen $(0.805 \mathrm{ml})$ of Godollo New Hampshire males.

Table 4. Effect of body weight on seminal plasma constituents (Mean \pm S.E)

\begin{tabular}{lccc}
\hline Seminal plasma const. & \multicolumn{2}{c}{ Body weight } & \multirow{2}{*}{ Significance } \\
\cline { 2 - 3 } & Light & Heavy & \\
\hline Total protein (g \%) & $4.21 \pm 0.35$ & $4.28 \pm 0.23$ & \\
Albumin (A) (g \%) & $1.40 \pm 0.04$ & $1.49 \pm 0.06$ & N.S. \\
Globulin (G) (g \%) & $2.80 \pm 0.26$ & $2.79 \pm 0.22$ & P $<0.05$ \\
A/G ratio & $0.52 \pm 0.04$ & $0.59 \pm 0.06$ & N.S. \\
Cholesterol (mg \%) & $100.5 \pm 1.66$ & $98.27 \pm 2.86$ & N.S. \\
Calcium (Ca) (mg \%) & $8.92 \pm 0.09$ & $7.25 \pm 0.30$ & N.S. \\
Inorganic Phosphorus (IP) (mg \%) & $5.25 \pm 0.16$ & $5.17 \pm 0.11$ & N.S. \\
Ca/IP ratio & $1.70 \pm 0.05$ & $1.40 \pm 0.07$ & P $<0.05$ \\
Alkaline phosphatase (U/100ml) & $3.96 \pm 0.07$ & $4.05 \pm 0.13$ & N.S. \\
Acid phosphatase (U/100ml) & $10.10 \pm 0.24$ & $10.51 \pm 0.37$ & N.S. \\
GPT (U/I) & $14.29 \pm 0.42$ & $13.86 \pm 0.34$ & N.S. \\
GOT (U/l) & $20.86 \pm 0.86$ & $20.00 \pm 0.66$ & N.S. \\
& & & \\
\hline
\end{tabular}

N.S. : not significant

Table 5. Effect of some blood plasma constituents on semen production (Mean \pm S.E.)

\begin{tabular}{lccc}
\hline Blood plasma const. & \multicolumn{2}{c}{ Semen production } & Significance \\
\cline { 2 - 3 } & $\begin{array}{c}\text { High semen } \\
\text { Production cocks }\end{array}$ & $\begin{array}{c}\text { Low semen } \\
\text { production cocks }\end{array}$ & \\
\hline Total protein (g \%) & $5.06 \pm 0.14$ & $4.33 \pm 0.15$ & $\mathrm{P}<0.01$ \\
Albumin (A) (g \%) & $1.51 \pm 0.03$ & $1.35 \pm 0.03$ & $\mathrm{P}<0.01$ \\
Globulin (G) (g \%) & $3.54 \pm 0.12$ & $3.08 \pm 0.16$ & $\mathrm{P}<0.05$ \\
A/G ratio & $0.44 \pm 0.02$ & $0.47 \pm 0.03$ & N.S. \\
Cholesterol (mg \%) & $129.57 \pm 3.16$ & $138.37 \pm 3.81$ & N.S. \\
Calcium (Ca) (mg \%) & $16.67 \pm 1.20$ & $15.33 \pm 1.24$ & N.S. \\
Inorganic Phosphorus (IP) (mg\%) & $9.68 \pm 0.40$ & $8.51 \pm 0.39$ & N.S. \\
Ca//P ratio & $1.72 \pm 0.08$ & $1.79 \pm 0.08$ & N.S. \\
Alkaline phosphatase (U/100ml) & $72.25 \pm 0.36$ & $70.35 \pm 0.40$ & N.S. \\
Acid phosphatase (U/100ml) & $3.36 \pm 0.26$ & $3.86 \pm 0.28$ & N.S. \\
\hline N.: not signiffan & & & \\
\hline
\end{tabular}

N.S. : not significant

\section{Fertility and hatchability}

\section{I - Effect of semen dosage and semen collection frequency on egg fertility and hatchability}

Table 6 shows that the percentage of the fertile eggs produced by hens inseminated with $0.15 \mathrm{ml}$. semen was insignificantly higher than that with either 0.05 or $0.10 \mathrm{ml}$. undiluted semen. The fertility percent of hens inseminated by semen collected once weekly was insignificantly higher than that by both twice and three times. Both insemination dosage and frequency of semen collection did not effect significantly on hatchability of eggs (Table 7). McCartney (1976) reported that the best fertility of commercial broiler breeder pullets was obtained by inseminating once weekly with $0.10 \mathrm{ml}$. undiluted semen. He found also that the hatchability percentages were $89.2,88.5$ and 87.5 when the hens were inseminated twice weekly with $0.10,0.05$ and $0.025 \mathrm{ml}$. undiluted semen, respectively. In this respect, McDaniel and Sexton (1977) reported that collection frequency of semen from the broiler-type males daily, twice daily and three times weekly, and from White Leghorn males weekly, three times weekly and five times weekly had no effect on fertility. 
Table 6. The effect of insemination dosage with undiluted semen and semen collection frequency on fertility $\%$ of Norfa hens

\begin{tabular}{|c|c|c|c|c|c|}
\hline \multirow[t]{2}{*}{ Insemination dosage $/ \mathrm{ml}$} & \multicolumn{3}{|c|}{ Semen collection frequency } & \multirow[t]{2}{*}{ Overall Average } & \multirow[t]{2}{*}{ Significance } \\
\hline & 3/weekly & 2/weekly & 1/weekly & & \\
\hline & \multicolumn{5}{|c|}{ 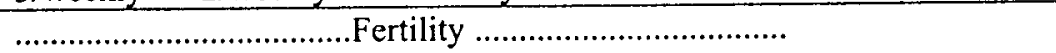 } \\
\hline 0.05 & 86.2 & 89.5 & 85.6 & 87.10 & \multirow{5}{*}{ N.S. } \\
\hline 0.10 & 83.8 & 84.1 & 90.4 & 86.10 & \\
\hline 0.15 & 90.9 & 84.96 & 91.2 & 89.02 & \\
\hline Overall average & 86.97 & 86.19 & 89.07 & 87.41 & \\
\hline Significance & 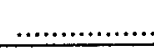 & 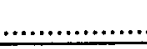 & $\ldots$ N.S... & .......... & \\
\hline
\end{tabular}

N.S., Not significant.

Table 7. The effect of insemination dosage with undiluted semen and semen collection frequency on hatchability $\%$ of Norfa hens

\begin{tabular}{|c|c|c|c|c|c|}
\hline \multirow[t]{2}{*}{ Insemination dosage $/ \mathrm{ml}$} & \multicolumn{3}{|c|}{ Semen collection frequency } & \multirow{2}{*}{$\begin{array}{l}\text { Overall } \\
\text { Average }\end{array}$} & \multirow[t]{2}{*}{ Significance } \\
\hline & 3/weekly & 2/weekly & 1/weekly & & \\
\hline & \multicolumn{5}{|c|}{ 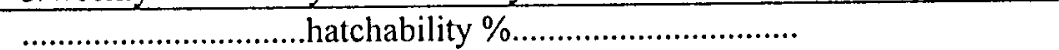 } \\
\hline 0.05 & 82.98 & 76.47 & 75.24 & 78.23 & \multirow{4}{*}{ N.S. } \\
\hline 0.10 & 78.50 & 82.10 & 80.85 & 80.48 & \\
\hline 0.15 & 76.36 & 75.00 & 75.81 & 78.72 & \\
\hline Overall average & 79.28 & 77.86 & 77.30 & 78.15 & \\
\hline Significance & & $\ldots .$. & & ........... & \\
\hline
\end{tabular}

N.S., Not significant.

\section{II - Effect of diluents and dilution rate on fertility and hatchability}

Data in Tables 8 and 9 indicate that the effect of both type of diluents and dilution ratio were not significantly on egg fertility and on hatchability. The fertility percentage of undiluted semen (control) and semen diluted with tris were higher than that of semen diluted with GCG. Regardless the diluter, the percentage of fertility of both $1: 3$ and $1: 5$ were quite similar. The dilution rate $(1: 3)$ of GCG was higher than $(1: 5)$ in fertility percentage. An opposite trend was noticed for Tris. It can be recommend that, using GCG diluter with dilution rate $1: 3$ but using Tris diluter with dilution rate $1: 5$ for insemination of Norfa hens. The hatchability percent of GCG diluter was higher than that either undiluted semen or Tris diluter, followed by undiluted semen (control). However, the differences in this respect were not significant. The dilution rate $(1: 5)$ of GCG was higher than $(1: 3)$ in hatchability percentage. The reverse was noticed for Tris. Kalamah (1993) found that in Norfa chickens the effect of dilution ratios $(1: 1,1: 3$ and $1: 5)$ and type of diluents $(0.9 \% \mathrm{NaCl}, 0.65 \% \mathrm{NaCl}$ and Ringer's solution) were significantly on hatchability. Regardless the extenders, the percentage of fertility was reduced by increasing the dilution rate, the difference between the dilution ratios $1: 1$ and $1: 3$ was not significant, however, both significantly $(\mathrm{P} \leq 0.01)$ differed from that diluted with $1: 5$. He added that hatchability percentage showed a reduction after using the highest dilution rate $(1: 5)$. Therefore, Sexton (1980) found that the fertility percentages were $62,76,83$ and 59 for semen dilution rate $1: 1$, $1: 3,1: 5$ and $1: 7$, respectively.

Table 8. The effect of diluters and dilution rate of semen on fertility \% of Norfa eggs

\begin{tabular}{|c|c|c|c|c|c|}
\hline \multirow[t]{2}{*}{ Dilution rate } & \multicolumn{2}{|c|}{ Diluters } & \multirow[t]{2}{*}{ Overall Average } & \multirow{2}{*}{$\begin{array}{l}\text { Control } \\
\text { (undiluted semen) }\end{array}$} & \multirow[t]{2}{*}{ Significance } \\
\hline & $\overline{\mathrm{GCG}}$ & Tris & & & \\
\hline & \multicolumn{4}{|c|}{ 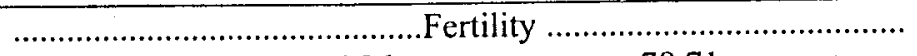 } & \multirow{5}{*}{ N.S. } \\
\hline $1: 3$ & 79.75 & 76.16 & 77.96 & 78.71 & \\
\hline $1: 5$ & 73.83 & 81.76 & 77.80 & 78.85 & \\
\hline Overall average & 76.79 & 78.96 & 77.88 & 78.78 & \\
\hline Significance & & & ............S.. & $\ldots \ldots \ldots \ldots \ldots$ & \\
\hline
\end{tabular}

N.S. not significant. 
Table 9. The effect of diluters and dilution rate of semen on hatchability $\%$ of Norfa eggs

\begin{tabular}{|c|c|c|c|c|c|}
\hline \multirow[t]{2}{*}{ Dilution rate } & \multicolumn{2}{|c|}{ Diluters } & \multirow[t]{2}{*}{ Overall Average } & \multirow{2}{*}{$\begin{array}{l}\text { Control } \\
\text { (undiluted semen) }\end{array}$} & \multirow[t]{2}{*}{ Significance } \\
\hline & $\overline{\mathrm{GCG}}$ & Tris & & & \\
\hline & \multicolumn{5}{|c|}{ 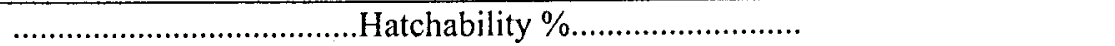 } \\
\hline $1: 3$ & 76.15 & 84.61 & 80.38 & 82.17 & \multirow{4}{*}{ N.S. } \\
\hline $1: 5$ & 93.64 & 75.15 & 84.40 & 82.11 & \\
\hline Overall average & 84.90 & 79.88 & 82.39 & 82.14 & \\
\hline Significance & & & ..........N.S... & ................ & \\
\hline
\end{tabular}

N.S. Not significant.

\section{Effect of vaginal $\mathrm{pH}$ on egg fertility}

The obtained results indicated that the vaginal $\mathrm{pH}$ of high fertility hens was lower than that of low fertility ones, it was $8.50 \pm 0.023$ and $8.87 \pm 0.020$ of high and low fertility hens, respectively. The differences in this respect, wer significant $(\mathrm{P} \leq 0.05)$. It means that the fertility was increased significantly with the decreased vaginal $\mathrm{pH}$. The present study suggest that the vaginal $\mathrm{pH}$ may be effect on spermatozoa activity in reproductive tract of hens. Kalamah (1990) found that there was significantly negative correlation between fertility and vaginal $\mathrm{pH}(-0.40)$ in duck .

\section{REFERENCES}

Abaza, M. J., Azza EL-Sebai, I. , Barnal, Szalay and L. Lennert, 1995. Semen quality and biochemical parameters of cockerels exposed to heavy metals. First Egyptian Hungarian Poult. conference. 17 19 Sept. 1995, Alexand ., Egypt.

Ansah, G. A.; JC. Segura and R. B. Buckland 1984. Influence of selection for fertility of frozenthawed semen in the chicken on semen production. Research reports, McGill univer., Depart. Animal Science, January 1984, 50 - 51, Ste - Anne de Bellevue, Quebec, Canada.

Attia, F. M. , N. F. Abdel Hakim, A. A. Amer and S. I. El-Sharkawy, 1984. Physical characteristics of fayoumi semen cocks as affected by dietary and seasons. Al- Azhar. J. Agric. Res. 2.

Benoff, F.H.; K. E. Rowe; J. I. Fuquay; J. A. Renden and G. H. Arscott 1981. Effect of semen collector on semen volume and sperm concentration in broiler breeder males. Poult. Sci. $60: 1062-1065$.

Bilgili, S. F.; J. A. Renden and K. J. Sexton 1985. Fluorometry of pouttry semen : its application in the determination of viability, enzyme leakage and fertility. Poult. Sci. $64: 1227-1230$.

Blesbois, E. and J. P. Caffin 1992. Serum like albumin of fowl seminal plasma and effects of albumin on fowl spermatozoa stored at $4.5 \mathrm{C}$. British. Poult. Sci., $33: 663-670 ; 32$ ref.

Bootwalla, S. M. and D. P. Froman 1988. Effect of extender viscosity on the insemination dose for chickens. . Poult. Sci. $67: 1218-1221$.

Bratkowski, A. 1975. Szybkie metodyn oznaczania fosforu, wapnia imagnzu Wsurowicy Krwi zwierzat. Mydycyna Wet. $3: 177$, Poland.

Btaszczyszyn, M. 1976. Oznaczana cholesterolu cotkowitego wsurowicy metoda bezposredina. Problemy Lekarskie 9: 219, Poland.

Buckland, R. B.; T. A. Scott and G. A. Ansah 1980. Genetic and environmental variation in semen production and fertility of chickens and turkeys. In : 9 th Int. Congr. Anim. production. Artificial insemination, volume 11. Madrid, Spain.

El- Hammady, H. Y. ; M. A. Abdellatif and K. M. Ali 1995. Effect of Naked Neck (Na) Gene, dietary protein level and their interaction on body weight and semen characteristics of chicken males. Egypt Poult. Sci., $15: 87-109$.

El-Sharkawy, S.I., 1981. Effect of some environmental factors on physical and chemical characteristics of poultry semen. Ph. D. Thesis Fac. of Agric. Al- Azhar univer..

E1- Zarkouny, S. A. 1994. The influence of carbosulfan and selenium treatment on some physiological parameters in rabbits. M. Sc. Thesis, Fac. of Agri. Al- Exand. Univer..

Gill, J. L., 1978. Design and analysis of experiments in the animal and medical sciences. Vol. 2. The Iowa State Univ. Press. Ames. Iowa. U. S. A.

Gornall, A. G.;C. J., Bardawill and M. M. David 1949. Determination of serum proteins by means of the biuret reaction. J. Biol. Chem. $177-751$.

Hafez, E. S. E. 1968. Reproduction in farm animals. Second edition, lea and Febiger, Philadelphia, P. $235-242$.

Hammond, M. C.; M. A. Boon and B. D. Barnett 1964. Some biochemical components of fowl semen. Poult. Sci., $43: 1326$.

Holcman, A.; R. Fabijan and M. Kovac 1993. The effect of 2- way selection for 56- day body weight 
in fowls on some reproductive traits of cocks. Zbornik - Biotehniske - Fakultete - Univerze Edvarda - Kardelja - V- Ljubljani,_Kmetijstvo.; No. 62; 143-151; 6 ref.

Kalamah, M. A. 1990. Utilization of artificial insemination and immunogenetical methods for improving reproduction in ducks. $\mathrm{Ph}$. D. Thesis, Fac. of Agric. Menofiya Univer.

Kalamah, M. A. 1993. Effect of semen dilution on sperm motility, fertility, hatchability and embryonic mortility of Norfa chicken.Menofiya J.Agric. Res., 18:1583-1599.

Kamar, G. A. R.; A. Obiedah ; N. E. Goher and M. A. Khalifa 1979. Genetical studies on semen characteristics of cocks. Egypt. J. Anim. Prod., 19: 101 - 103.

Kind , P. R. N. and E. J. King 1954. Estimation of plasma phosphatases by determination of hydrolysed phenol with aminoantipyrine . J. Clin . Path ., $7: 322$.

Krawczynski, J. and T. Osinski 1962. Laboratoryine matody diagnostijczne. Pzwl, Warzawa, Poland.

Kunev, K. and I. Manolov 1988). The effect of body weight development and age of sexual maturity of cocks on semen quality and reproductive performance. Zhivotnov "Nauki; $25: 39$ - 44;15 ref.

McCartney, M. G. 1976. The effect of semen dosage and insemination frequency on the fertility of broiler breeder hens. Poult. Sci, $55: 669$ - 671

McDaniel, G. R. and T. J. Sexton 1977. Frequency of semen collected in relation to semen volume, sperm concentration and fertility in the chicken Poult. Sci. , 56:1989-1993.

Nagae T. ; K. Nobukuni and H. Nishiyama 1987. Effects of thyroid hormone deficiency after sexual maturity on weights of male genital organs and semen quality in domestic fowls. Japanese. Poult. Sci., $24: 32-38,30$ ref.

Ramamurthy, N. ; D. Naraharj ; P. Kothandaraman and V.Sethumadhavan 1989. Influence of age and body weight on the semen characteristics of white Cornish sires. Indian Veterinary J., 66: $584 ; 2$ ref.

Reitman , S. and S. Frankel 1957. A colorimetric methods for determination of serum glutamic oxalacetic and glutamic pyruvic transinase. Am. J. Clin. Pathol., $28: 56$ - 63.

Ressequie, W. D. and B. L. Hughes 1984. Phospholipid and cholesterol profiles from chicken seminal components during in vitro storage at 5 C.Pouit. Sci., $63: 1438-1443$

Rodkey, F. J. 1965. Direct spectrophotometric determination of albumin in human serum. Clin. Chem. $11: 478$.

Saeid, J. M. and K. A. Al- Soudi 1975. Seasonal variation in semen characteristics of white Leghorn, New Hampshire and indigenous chicken in Iraq. British . Poult. Sci., 16: 97- 102.

Sexton, T. J. 1980. Effect of prefreeze treatment on the fertilizing capacity of frozen chicken semen. . Poult. Sci., $60: 1552$ - 1557.

Snedecor, G. W. and Cochran 1973. Statistical methods. Iowa State University Ames. 